DOI: $10.35643 /$ Info.26.1.10

Dossier temático: Ética de la Información

\title{
The Internationalization of Research and Teaching in Information Ethics: A post-2018 Review
}

\author{
La internacionalización de la enseñanza y la investigación en Ética de la \\ Información: una revisión posterior a 2018
} A internacionalização da pesquisa e do ensino em ética da informação: uma
revisão pós-2018

\begin{abstract}
Jared Bielby ${ }^{\mathrm{a}}$
Rachel Fischer $^{\mathrm{b}}$

${ }^{a}$ International Centre for Information Ethics, Chair, Canada. ORCID: 0000-0001-7364-389X Correo electrónico: bielby@ualberta.ca.

${ }^{\mathrm{b}}$ International Centre for Information Ethics, Co-Chair, South Africa. ORCID: 0000-0002-11558224. Correo electrónico: rachel@,3consulting.org.
\end{abstract}

\begin{abstract}
The International Center for Information Ethics (ICIE), founded in 1999 by Uruguayan philosopher Rafael Capurro, offers a global-wide platform for collaboration in teaching, publishing and practicing information ethics. For over two decades, ICIE has led and supported initiatives, publications and conferences on topics critical to information cultures in the digital age, dealing with everything from algorithmic bias and robot ethics to traditional information science. Through the formation of international and intercultural partnerships, ICIE has established its well-earned reputation as the leading voice of Information Ethics around the world. The greatest legacy of ICIE rests in its early support of, and lasting partnership with, the African Network for Information Ethics (ANIE) and the African Centre of Excellence for Information Ethics (ACEIE). The following article is a reflection on the role and influence of ANIE since 2007 and the ACEIE since 2012, via the support of ICIE towards internationalising Information Ethics in Africa. It will be shown that the grounded approach of ACEIE towards the development of information cultures across Africa provided ICIE with the needed structure and framework to anchor its wider academic focus in an authentic understanding of and respect for the life-worlds and value systems of not only Africans but of people all over the world.
\end{abstract}

Keywords: INFORMATION ETHICS; AFRICA; ICIE; ANIE; ACEIE. 


\section{Resumen}

El Centro Internacional para la Ética de la Información (ICIE), fundado en 1999 por el filósofo uruguayo Rafael Capurro, ofrece una plataforma global para la colaboración en enseñanza, producción de documentos y práctica de la ética de la información. Por más de dos décadas, ICIE ha liderado y sostenido iniciativas, publicaciones and eventos académicos sobre tópicos críticos de las culturas de la información en la era digital, tratando todo lo relacionado con desviaciones éticas de los algoritmos y los robots respecto a la ciencia de la información tradicional. A través de la formación internacional y la colaboración intercultural, ICIE ha establecido su bien ganada reputación como la voz de liderazgo en ética de la información alrededor del mundo. El legado más importante de ICIE reside en su temprano y duradero apoyo de colaboración con la Red Africana para la Ética de la Información (ANIE) y el Centro Africano de Excelencia para la Ética de la Información (ACEIE). El artículo es una reflexión sobre el rol y la influencia de ANIE desde 2007 y del ACEIE desde 2012, a través del apoyo de ICIE en favor de la internacionalización de la ética de la información en África. Se mostrará que el enfoque de ACEIE que da fundamento al desarrollo de las culturas de la información a través de África proporciona a ICIE el marco teórico y la estructura necesarios para anclar su amplio foco académico en un entendimiento auténtico respecto a los sistemas de valores y formas de vivir no solo de los africanos, sino de la gente alrededor del mundo.

Palabras clave: ÉTICA DE LA INFORMACIÓN; ÁFRICA; ICIE; ANIE; ACEIE.

\section{Resumo}

O Centro Internacional de Ética da Informação (ICIE), fundado em 1999, pelo filósofo uruguaio Rafael Capurro, oferece uma plataforma global de colaboração no ensino, publicação e prática da ética da informação. Durante mais de duas décadas, o ICIE tem liderado e apoiado iniciativas, publicações e conferências sobre temas críticos para as culturas da informação na era digital, lidando com tudo, desde o preconceito algorítmico e a ética robótica até à ciência da informação tradicional. Através da formação de parcerias internacionais e interculturais, o ICIE estabeleceu a sua merecida reputação como a principal voz da Ética da Informação em todo o mundo. Talvez o maior legado do ICIE, contudo, não resida nos seus próprios sucessos, mas antes no seu apoio precoce e parceria duradoura com a Rede Africana de Ética da Informação (ANIE) e o Centro Africano de Excelência em Ética da Informação (ACEIE). O artigo seguinte é uma reflexão sobre o papel e a influência da ANIE desde 2007 e da ACEIE desde 2012, através do apoio do ICIE à internacionalização da Ética da Informação em África. Será demonstrado que a abordagem fundamentada da ACEIE para o desenvolvimento de culturas da informação em toda a África, forneceu ao ICIE, por sua vez, a estrutura e o enquadramento necessários para ancorar o seu foco acadêmico mais amplo numa autêntica compreensão e respeito pelo mundo da vida e pelos sistemas de valores não só dos africanos mas também de pessoas de todo o mundo.

Palavras-chave: ÉTICA DA INFORMAÇÃO; ÁFRICA; ICIE; ANIE; ACEIE. 
Received: $\quad 20 / 08 / 2020$

Accepted: $\quad 02 / 05 / 2021$

\section{Introduction and purpose}

Via its journal, the International Review of Information Ethics, ICIE has pioneered much of the research that is only now being considered crucial by government and industry towards the establishment of a successful and equitable digital society. Through its many partnerships and conferences, ICIE has established localized chapters around the world, and continues to expand its influence through the development of new chapters, even as the world enters a post-COVID era. Relaunched in 2018 under a new community-led philosophy, ICIE is in the process of redefining its goals and mission. Through its communityled model, it is working to re-establish and define the parameters of the field of Information Ethics for a new generation.

Upon the retirement of its founder and director, Dr. Rafael Capurro, ICIE was relaunched during 2018 under a new vision and administration, and is now hosted by the Kule Institute for Advanced Study at the University of Alberta, Canada. Since its relaunch, ICIE has established new chapters in North Africa, India and Latin America. It has set the foundations for the development of an ICIE-led Curriculum Consortium which will support the creation and teaching of courses in the field of Information Ethics via new partnerships with universities around the world. The nature of the success of ICIE's community-led philosophy, however, cannot be truly understood without first comprehending the history and process of the grounded community approach that led to the internationalisation of Information Ethics in Africa by ACEIE over the last two decades. The following article is therefore devoted to a description of the steps the ACEIE and ICIE took to achieve internationalisation of Information Ethics in Africa since 2007 and will endeavour to show how these steps played a critical role in the successful development of ICIE's new community-led philosophy. 


\section{Background and Theoretical Foundations}

The world in which we live today is radically different from the world in which any previous generation made their living. It is a world characterized not only by information communications technology, which enables people from all over the world to interact with one another 24 hours a day, but also by nanotechnology, energy storage, 3D printing, artificial intelligence, robotics, the internet of things, drones, automatic vehicles, medical and biotechnology, all of which potentially affect the way people manage their life worlds. All of these have the potential to either benefit or harm mankind, hence the need for some or other code of conduct regulating, either implicitly or explicitly, the way in which they are used. It was, amongst others, to develop such a code of conduct that UNESCO convened a World Summit on the Information Society, Geneva 2003 - Tunis 2005.

The code of conduct emerging from the World Summit on the Information Society (WSIS), referred to as Information Ethics, was specifically aimed at regulating the way in which people engage with information communications technology (ICTs). Informing this code was the assumption that, if these technologies were used responsibly, they had the potential to contribute to the alleviation of poverty and hunger, the provision of primary education for all, the eradication of gender and other inequalities, the reduction of child mortality, the improvement of health, and the forming of global partnerships which could result in a more peaceful, just and prosperous world (WSIS, 2003). The Declaration on Information Societies resulted in the Geneva Declaration of Principles, the Geneva Plan of Action, the Tunis Commitment, and the Tunis Agenda for the Information Society (WSIS, 2005).

The definition of Information Ethics which emerged from the WSIS, informed by values espoused in classical Western/European philosophies, while reflecting values assumed to be universal, was not, however, a "transcultural canon of values and principles, such as the ones stated in universal declarations protecting, for instance, human rights" (Capurro, 2007). Instead, it was meant to serve as a platform for debates and deliberations on the similarities and differences between these, primarily Western, value system and those of other nations and cultures with the view of establishing an information ethics that could direct ICT usage all 
over the world. It was, amongst others, to initiate such a debate in Africa that the first international conference on Information Ethics (IE) to be held on the African continent, took place in Pretoria (Republic of South Africa) in February 2007 (ANIE, 2007a).

What emerged from this conference in terms of the WSIS definition, were three seemingly dominant positions. The first of these was that the imposition of a Western/European-oriented view of Information Ethics could have a negative impact on "national, local and indigenous cultures" in Africa, and that adherence to it should be approached "cautiously" to ensure that it does not further the erosion and marginalization of "indigenous knowledge and value systems" already caused by colonialism (Mashabi, 2013:42). The second position was that it was not impossible to 'marry' Western and African values, traditions and philosophies given the many similarities between African value systems and those in other parts of the world (Capurro, 2013; Ocholla, 2013). According to Capurro (2013a), African philosophy reflects an eclectic mix of not only ancient Egyptian and Greek philosophies into but also of more recent Marxist, Socialist, Communist and Capitalist ideas on social, political and economic reconstruction. The third position, earlier espoused by Burnett et al. (2004), was that digital technologies are not neutral: they create new ways of being, influence people's relations with one another and shape institutions, economies and moral values in more or less radical ways, changes to which, according to Mashabi (2013:42) all digital citizens have to adapt. The one thing on which all conference delegates agreed was that, unless the peoples of Africa used digital technologies responsibly and ethically, the consequences of its use could be devastating (Mutula, 2013).

Informed by their deliberations as well by the emphasis on inter-culturalism in the WSIS Declaration on Information Societies, delegates at the 2007 ANIE Conference formulated their own 'African' Declaration on African IE. Encapsulated in this declaration, which was referred to as 'Tshwane Declaration on Information Ethics for Africa', was delegates' vision of an African society committed to peace, the upholding of fundamental values (freedom, equality, solidarity and tolerance), shared responsibility, and respect for nature (ANIE, 2007b). Delegates believed that by committing themselves to uphold these 
principles, they not only indicated their support for the 'universal' principles informing various international declarations (i.e. the United Nations Charter; International Law and Multilateralism; the Universal Declaration of Human Rights; the WSIS; and the Millennium Development Goals), but also made a "genuine African contribution to the UNESCO Code of Ethics" for Information and Knowledge Societies (Capurro, 2013b).

\section{Internationalization in Africa}

The basis for the internationalization of Information Ethics in Africa was laid at the 2007 Information Ethics Conference referred to in the introduction. Held under the auspices of UNESCO, sponsored by the South African Government Department of Communications, and co-organized by the International Centre of Information Ethics and the universities of Pretoria (RSA), Wisconsin-Milwaukee (USA) and Pittsburgh (USA), it was attended by an international group of 80 policy-makers and academics from across the world. The dual purpose of the conference was to (a) discuss the impact and use of modern ICTs on the African continent, and (b) to formulate specific, African perspectives on local and global challenges associated with the use of these technologies. Informing these discussions was not the question of how to convince Africans to accept Western perspectives on Information Ethics and its roles/function, but how the conceptualisation and contextualisation of IE theories and relationships between ethics, laws and morals on the one hand, and multi-culturalism, trans-culturalism and inter-culturalism on the other, could help to define and explain African Information Ethics (Ocholla, 2013:27).

Africa, according to Ocholla (2013), differs from other continents in four ways if it is viewed "through the lens of colonial or modern socio-political, economic or technological challenges": first, some of the 54 countries making up Africa are ruled much like Western democracies while others are ruled by dictators, despots or anarchists; second, African culture is a complex and hybrid mix of traditions, languages, values, religions and beliefs; third, it is still primarily rooted in the Agricultural or early Industrial Age; fourth, it is the continent with the fastest mobile phone growth rate in the world. Despite these differences, all of these 
countries subscribe to some degree to the notion of 'ubuntu', an umbrella term for a philosophical orientation which emphasizes the nature of humanity in terms of recognizing and affirming the humanity of all people by, inter alia, establishing humane, respectful relationships (Ramose, 2004), sharing and caring for one another in order to become 'a person through other persons" (Olinger, Britz and Olivier, 2005:293). Put differently, all Africans subscribe to the principle of “communal existence" (Brannigan, 2002/2005), symbiotically "living with and through the other" (Senghort, 1964:72/73), without necessarily having to sacrifice their own cultural beliefs, traditions and/or languages.

It is this last point, living with and through the other without having to sacrifice one's own beliefs, traditions or culture, which distinguishes internationalization from globalization. Whereas plurality is preserved in the former, it is, by implication, negated in the latter and, more specifically, if globalization is to result in a single, 'global village'. Whereas the premise on which globalization rests is universality, the premise on which internationalization rests is unity in diversity. It follows that concerted efforts to globalize the world would have as a key objective the assimilation of all cultures, traditions, beliefs and/or languages into a single global one. The key objective of internationalization, however, is not assimilate any culture into another, nor to force people to associate or bond with others whose values are markedly different from theirs. Rather, its purpose is to create opportunities for multiple "cross-cultural dialogues, marked by a fundamental respect .... for the irreducible differences that define our cultures and identities" (Ess, 2007:98). If bonding were to happen, it should be because such bonding would create a life that is broader and fuller than the one in which they happen to find themselves at any particular moment (Taylor, 2002:191). That such bonding was possible was already evident from the way in which delegates at the 2007 international conference related to and interacted with one another.

It was to strengthen and expand this kind of bonding on IE issues that informed the ACEIE's IE advocacy strategy, aligning itself more closely to the International Centre for Information Ethics (ICIE). More specifically, the ACEIE committed itself to include in all its IE advocacy activities, opportunities for people to discuss ways in which IE could not only be used to add value to indigenous knowledge 
and value systems but also to find ways in which these systems could broaden/expand Western/European philosophical perspectives on Information Ethics (Ess, 2007:114; Frohmann, 2007:139). To this purpose, ANIE conferences and ACEIE workshops would, where possible and applicable, include deliberations on ways in which digital technologies could be used to authenticate, map and restore marginalised African knowledge systems (Meshabi, 2007; Msuya, 2007; Löwstedt, 2007:205; Ocholla, 2007:242) on the one hand, and to stem the African "brain drain" (Britz, 2007), on the other.

\section{ACEIE Internationalization Strategy}

The African Centre for Excellence of Information Ethics (ACEIE) was formally established in 2012 with the primary purpose of raising awareness of Information Ethics in Africa. The ACEIE was established at the Department of Information Science, University of Pretoria. Informed by the views summarised in the preceding two sections, as well as by the Tshwane Declaration on Information Ethics in Africa, the ACEIE decided to adopt an accommodative, intercultural/inter-national, rather than an assimilative, universal/global, approach to the advocacy of IE in Africa. The platform for the promotion of internationalism was laid at the 2007 international IE Conference in Pretoria. One of the outcomes of this conference, which contributed greatly to the promotion of internationalism, was the creation of a digital Africa Network for Information Ethics (ANIE), which would enable academics, policy makers and whoever else might be interested in IE issues, teaching or research to interact with one another on these matters (ANIE, 2007a).

While the creation of the ANIE was not an ACEIE initiative, its management and expansion became an ACEIE responsibility after its establishment in 2012. The ANIE was also the key instrument by means of which the ACEIE informed ANIE subscribers in Africa and other parts of the world of IE-related conferences, kept them up to date with the latest developments in the IE field, encouraged and supported IE research initiatives, and stimulated debates/discussions on all of these. In encouraging African countries at workshops and conferences to establish their own ANIE chapters, the ACEIE also contributed to the expansion of the 
network and, by implication to the internationalization of Information Ethics in Africa and elsewhere in the world.

During the period 2012-2017, the ACEIE, in conjunction with the DoC (later renamed as the DTPS (Department of Telecommunications and Postal Services), UNESCO, and its international partners in Europe and the USA, convened four more ANIE conferences, each focusing on a different IE issue. Since these conferences were attended by people from all over the world, they implicitly contributed to the internationalization of IE and related issues. Not only did conferences like these, each focusing on a different IE theme, facilitate international networking critical to the development of Information and Knowledge Societies in Africa, but they also contributed to an increase on African IE by academic from all over the world, but especially from Africa. It was at these conferences that academics shared their Information Ethics experiences and perspectives with one another, thus creating a better understanding and appreciation of similarities and differences between their own and others' views on IE and the roles it could/should play, and the challenges these pose to the internationalisation of IE.

Apart from serving as platforms for IE deliberations/discussions, ANIE and other IE-related conferences were critical to ensuring that African perspectives on IE were included in global IE debates. Issues debated at these conferences, leading to publication or further research included the use and abuse of social media, cybercrime, e-Learning, IE teaching and learning, IE and the Law, IE policy development, poverty alleviation, food security, and Information Management (ACEIE 2013, 2014, 2015, 2016, 2017). The attendance of and delivery of papers by Africans at these conferences was especially important since IE research by African academics had, prior to the 2007 conference, lagged far behind IE research in other countries. Not only were all the papers delivered at these conferences research-based, but many of them were eventually published in academic journals all over the world, thus sensitizing the rest of the world to what is happening in Africa regarding IE.

The compilation of the Africa Reader on Information Ethics, consisting solely of selected papers delivered at the 2007 ANIE conference, for example, played a 
seminal role in the motivation of African academics to conduct and publish their IE research. Including papers reflecting Western, Eastern, and African perspectives on IE and the impact of ICTs and IE on individuals, groups and nations, it not only stimulated north-south IE debates but also north-south research.

Another publication which stimulated IE research was a Handbook for Higher Education Institutions (HEIs), which was already offering, or planning to offer IE in the future. The suggestion for a Handbook like this was made at an ACEIE Project Planning Workshop in March 2012 with a view to the need for Handbooks to support the pending development of a university curriculum for IE in Africa. Academics deemed to be IE experts were identified at the workshop as potential authors and requested to write one or more chapters relevant to the teaching of IE at universities. To this purpose, all the authors had to ensure that what they wrote was verifiable - hence they had to utilize existing research findings or conduct their own research on the topic they were writing about. Not only the authors reflected the 'international' nature of the Handbook but also its title, 'Information Ethics in Africa: Cross-cutting Themes'.

The development and roll-out of the IE Curriculum Framework for Higher Education Institutions, a project started by the ANIE soon after the 2007 Conference, and completed by the ACEIE in 2013, was specifically aimed at the creation of internationalism or, put differently, at achieving 'unity in diversity'. The original aim was to develop a standardized, 'one-size-fits-all' curriculum that would be mandatory at all participating universities on the continent. However, the need to acknowledge and accommodate differences between countries and institutions regarding context, culture, tradition, etc., regularly emphasised at IE conferences and consultative ACEIE curriculum workshop, resulted in the eventual development of a standardized Curriculum Framework. HEIs interested in offering IE programs would then, using the Framework as basis, have the freedom to design IE programs which were appropriate to their particular contexts (needs, challenges, contexts, value system, philosophical orientations, etc.) but which, at the same time, satisfied the requirements for IE curriculum design and delivery set out in the Framework. Since workshops leading to the development of 
the Framework were run in different African countries, and drafts of the Framework were posted on ANIE and discussed at ANIE conferences, both it and the institutional curricula designed within its parameters could be seen as contributing to the ACEIE's internationalisation mission.

The ACEIE, partnering with INTEL, also used the schooling sector as a vehicle for the promotion of internationalization. Their Digital Wellness Toolkit for Schools and Communities in South Africa, was also marketed in Lesotho, Namibia, Swaziland, Mozambique, Uganda, Zimbabwe, Malawi and Kenya, the latter subsequently 'localizing' it for their conditions, and committing itself to reformatting it as an educational television programme for schools (ACEIE 2015; 2016). Since the workshops formed part of a UNESCO-sponsored project, and were conducted in accordance with the UP-UNESCO agreement, all of them were hosted by the UNESCO Commissions based in these countries, and representatives of the commission concerned were included in the cohort of academics and government officials presenting papers and/or acting as facilitators at all of them. A key outcome of the collaborative presentation and facilitation of these parties was the subsequent forming of inter-national university and commission interest groups.

Since the on-going support of UNESCO, at whose 2003 WSIS the worldwide IE advocacy initiative was launched, was critical to the successful internationalisation of IE in Africa, the ACEIE ensured the attendance of one or more of its staff members at meetings, seminars and/or conferences of UNESCO in Paris (France) and/or of its structures in Africa as well as the UNESCO, CI and IFAP committees in South Africa. Moreover, it involved representatives of these UNESCO structures and committees in as many of its own activities as possible. In doing so, the ACEIE not only strengthened its relations with UNESCO as an international body but also ensured that the IE concerns and challenges of Africa formed part of international discussion and deliberations.

Other ways in which the ANIE/ACEIE wanted to nurture internationalism was through the promotion of North-South research. To this purpose it planned to create opportunities for IE researchers in Africa to publish their findings in academic journals. Collaboration with research partners were central to this 
strategy, ensuring the establishment of the African ICIE Chapter, headed by Coetzee Bester, Director of the ACEIE.

\section{Results \& Achievements of the Internationalization of IE}

Having summarised ACEIE activities which either implicitly or explicitly contributed to the internationalization of IE and, in turn, to the wider communityled philosophy of ICIE, it can be concluded that these activities not only led to greater engagement on, and authentic insights into IE issues and challenges in African countries but also in the rest of the world via their influence on the wider activities of the International Center for Information Ethics. The ACEIE's success in this regard is evident in the active engagement of at least 300 subscribers to ANIE, the increase in IE research articles by African academics, the introduction of stand-alone IE programmes or short courses at HEIs on the African continents and/or the integration of IE themes in existing HEI programmes, the localization of the South African Digital Wellness Toolkit for schools and communities, the quality of papers delivered at IE-related workshops and conferences, and the increased attention that African governments and private sector companies in Africa are paying to the development of IE policies and training programs (Fischer \& Malan, 2019).

The importance of sound research as a basis for all of these as well as the need to take cognizance of differences in the ways in which research findings would be implemented in different contexts are acknowledged by UNESCO, academics, policy developers, the private and education sectors, and governments across the world. There is, therefore, indications of international agreement that IE research is not merely a 'nice-to-have' but a necessity for the development of international understanding, cooperation, and respect within the digital structures of information societies.

The commitment of African scholars to promote and engage in research is evident, not only from the fact that IE-related papers at all conferences (irrespective of the themes and/or topics addressed) were research-based, but also in the emphasis placed on Information Ethics at conferences, the increased publication of IE research articles in academic journals, the extent of research that 
preceded the development of IE programmes and resource materials, and the training of students as IE researchers at higher education institutions across the continent.

The importance that academics and policy makers attach to research as a component of development is evident from the emphasis they place on the need to conduct IE research that would contribute to the restoration of the human dignity of Africa's peoples, the erosion of corruption at all levels of society, and ways of developing African countries as Knowledge and Information societies. It is therefore not surprising that much of the IE research conducted on the continent since 2007 has focused on the potential impact of globalisation and a digital culture on society, the preservation and/or resuscitation of marginalised African knowledge and value systems, access to and the accessibility of information for all, the prioritisation of quality education, and the need for IT literacy training.

\section{From Africa to Oxford}

Following the lead of ACEIE and ANIE, the very entities that ICIE helped establish and support in their own foundation and growth, the International Center for Information Ethics has in turn officiated a new community-led philosophy in 2018 based on a theory of localized, ground-up engagement with regional cultures. This pragmatic approach to engagement had already been informing the academic community and pursuits of ICIE for almost a decade before it was officiated upon ICIE's relaunch. Much like the ACEIE curriculum framework outlined above, the ICIE academic community recognized that a single unified approach not only failed to meet the needs of the localized populations of Africa, but it also resulted in the continuation of a systematic enforcement of westernbased philosophies and views. Influenced by the internationalization coming out of Africa, the academic community of ICIE, led by Rafael Capurro, introduced the foundation for a new branch of the field in 2007, a branch that would aptly be called Intercultural Information Ethics (IIE) (Capurro, R. 2008). The creation of IIE formalized the internationalization process.

The recent academic initiatives of ICIE have led forward using the above approach as outlined under ICIE's newly adopted mission. In doing so, such 
initiatives reflect the internationalization concepts first developed by ACEIE and ANIE. These initiatives include the ICIE-led Classical Ethics chapter of IEEE's Ethically Aligned Design (IEEE Global Initiative, 2017), the development of the International ICIE Curriculum Consortium, and the recent AI4IA event addressing information accessibility, hosted in collaboration with the Kule Institute for Advanced Studies (KIAS), ICIE, the UNESCO Cluster Office for the Caribbean, Kingston, Jamaica and the UNESCO Regional Office for Southern Africa, Harare, Zimbabwe (ICIE: Artificial Intelligence for Information Accessibility, 2020).

The intercultural and community-led philosophy for research and teaching in Information Ethics has become internationalized across the globe and transcends both industry and academia, being taken up recently even by Oxford's Digital Ethics Lab. Being influenced by, and following the lead of IEEE's Classical Ethics committee, Oxford organized a one day Intercultural Digital Ethics Symposium on December 10, 2019 "to foster a conversation on the relevance and importance of pluralist perspectives on digital ethics" (Digital Ethics Lab, 2019). The Symposium hosted a number of speakers and organizers from the EAD Classical Ethics Committee, including Corinne Cath-Speth, Marie-Therese Png, Jared Bielby, Pak-Hang Wong, as well as one of the pioneers of IIE, Charles Ess. The main event of the symposium focused on a panel that hosted a debate between Charles Ess' IIE theory of irreducible differences, and Pak-Hang Wong's critique of it.

\section{Conclusion}

The African Internationalization of IE culminating among the ivory towers of academia is a testament to the value of a philosophy that prioritizes the authentic localized experience. As highlighted above, the western philosophical tradition shares a number of commonalities with non-western traditions. Such commonalities have to be experienced before they can be labelled and the experiential encounter can only take place in a localized setting. The hidden commonalities between cultures are what allow for an authentic face-to-face interaction with an 'other'. As the African Ubuntu saying goes, "I am because we are." Over the two decades of its existence, ICIE has both consciously and 
unconsciously adopted the African experience of information societies, as is reflected in its focus on establishing both North-South and South-South relationships.

The ACEIE views it as an imperative that, while South-South networks must be strengthened to ensure research of a high quality, North-South research networks must not be neglected. The African internationalization of IE as tandem to the creation of a viable IIE theory will ensure that Africa not only remains a part of the global information and knowledge society but a key player in it. The legacy of the ACEIE and ANIE pioneering accomplishments are reflected in the ICIE community-led philosophy which approaches the global information and knowledge society as consisting of not one information society, but rather information societies (plural) that are, as Charles Ess puts it, "irreducible" (Ess, C. 2007). As stated in the newly established ICIE mission statement, the ICIE community "advocates for and supports the growth of healthy and informed information cultures in the digital age" (ICIE: Mission Statement, 2020).

\section{Bibliography}

ACEIE (2011). Official memorandum of agreement between the University of Pretoria and the South African National Department of Communication, signed on 15 December 2011. Pretoria.

ACEIE (2013). 2012 Annual Report. March 2013. African Centre for Excellence of Information Ethics.

ACEIE (2014). 2013 Annual Report. March 2014. African Centre for Excellence of Information Ethics.

ACEIE (2015). 2014 Annual Report. March 2015. African Centre for Excellence of Information Ethics.

ACEIE (2016). 2015 Annual Report. March 2015. African Centre for Excellence of Information Ethics.

ACEIE (2017). 2016 Annual Report. March 2016. African Centre for Excellence of Information Ethics.

ANIE (2007a). Conference Report: The Joy of Sharing Knowledge. Pretoria.

ANIE (2007b). Tshwane declaration on Information Ethics in Africa. Adopted on 7 February 2007 at Africa Information Ethics Conference. Pretoria. RSA. 
ANIE (2009). Report on UNESCO Information ethics and e-governance in subSaharan Africa workshop. Magaliesburg, RSA.

ANIE (2010). Africa Information Ethics: The Road Ahead. Conference Report. University of Botswana, 6-7 September 2010. Gaborone, Botswana.

ANIE (2012) Conference. Conference Report. University of Pretoria. Pretoria. Republic of South Africa.

Bester, C and Bothma, R. (2013). Chronological discussion of ANIE events 2007 - 2012. Unpublished article. African Centre of Excellence for Information Ethics. University of Pretoria. Pretoria. RSA.

Bester, C., Malan, B.M. (2015). Digital Wellness Toolkit. African Centre of Excellence for Information Ethics. Group 7 Publishers. Pretoria.

Brannigan, M. C. (2005). Ethics Across Cultures with Power Web Ethics. McGraw-Hill

Britz, J. J. (2004). Africa and its Place in the Twenty-First Century: A Moral Reflection. In: Mendina, T. and Britz, J. J. (Eds): Information Ethics in the Electronic Age. Current Issues in Africa and the World. North-Carolina. McFarland, 5-6.

Britz, J. J. (2007). The joy of sharing knowledge: But what if there is no knowledge to share? A critical reflection on human capacity building in Africa. Published in the Africa Reader on Information Ethics (page 15 to 22). ISBN: 978-0-620-45627-2. Department of Information Science. University of * Pretoria. South Africa. First electronic edition: 2007, First printed edition: 2012.

Britz, J. (2013). Understanding information ethics. Information ethics in Africa: Cross-cutting themes, 1-6.

Capurro, R. (2007). Information Ethics for and from Africa. The International Review of Information Ethics, 7, 6-17.

Capurro, R. (2008). Intercultural information ethics. The handbook of information and computer ethics, 639.

Capurro, R. (2013). Information ethics in the African context. Information Ethics in Africa: Cross cutting themes, 7-20.

Capurro, R., Britz, J. J., Bothma, R., Bester, C. (2007). Foreword. Africa Reader on Information Ethics, 3-14. Department of Information Science. University of Pretoria. South Africa. available online at https://www.up.ac.za/african-centre-of-excellence-for-information- 
ethics/article/2087835/books. First electronic edition: 2007, First printed edition: 2012. ISBN: 978-0-620-45627-2.

Castells, M. (2000). The Rise of The Network Society: The Information Age: Economy, Society and Culture. Volume 1. Retrieved from https://books.google.pt/books/about/The_Rise_of_The_Network_Society. $\% 20 \mathrm{html}$ ? id=hngg4aFtJVcC\&pgis $=1$

Ess, C. (2007). Cybernetic pluralism in an emerging global information and computing ethics. In: Capurro, R., Britz, J. J., Bothma, T. J. D. \& Bester, B. C. (Eds). Africa Reader on Information Ethics. 91-114. Pretoria. Department of Information Science: University of Pretoria. 91-114

Ess, C (2009). Digital Media Ethics. Cambridge. Polity Books.

Fischer, R., Malan, B. (2019). The Development of the Digital Wellness Toolkit. In: Proceedings of the 12th ICEGOV conference on Theory and Practice of Electronic Governance. Published by ACM Press.

Frohmann, B. (2007). Assembling an African Information Ethics. International Review on Information Ethics (IRIE). Vol. 7.

International Center for Information Ethics. (2020). Artificial Intelligence for Information Accessibility Retrieved from https://www.i-c-ie.org/inclusive-ai (2020, September 23).

International Center for Information Ethics. (2019). ICIE Curriculum Consortium for Information Ethics. Retrieved from https://www.i-c-i-e.org/courses (2019, July 02)

International Center for Information Ethics. (2020). Mission \& Goals. Retrieved from https://www.i-c-i-e.org/missions-and-goals (2020, September 3).

IEEE Global Initiative on Ethics of Autonomous and Intelligent Systems. (2017). Ethically Aligned Design: A Vision for Prioritizing Human Well-being with Autonomous and Intelligent Systems, Version 2. IEEE, 2017. Retrieved from https://ethicsinaction.ieee.org/

Löwstedt, A. (2007). Cultural extinction as an aspect of current globalization trends. African Information Ethics Conference. Pretoria, RSA. 5-7 February 2007

Malan, B.M., Bester, C. (2014). Curricuulum to teach Information ethics at universities in Africa. Pretoria. African Centre of Excellence for Information Ethics. University of Pretoria. Pretoria. RSA.

Meshabi, M. (2007). The Third World and the paradox of the digital revolution. In: R. Capurro, J.J. Britz, T.J.D. Bothma and B.C. Bester (eds). Africa 
Reader on Information Ethics. Department of Information Science. University of Pretoria. Pretoria. pp 39-42

Msuya, J. (2007). Challenges and opportunities in the protection and preservation of indigenous knowledge in Africa. In Capurro, R., Britz, J. J., Bothma, T. J. D. \& Bester, B. C. (Eds). Africa Reader on Information Ethics. Department of Information Science. University of Pretoria: 343-349.

Mutula, S. M. (2004). Making Botswana an information society: current developments. The Electronic Library, 22(2): 144-153. http://doi.org/10.1108/02640470410533407

Mutula, S. M. (2008). Digital divide and economic development: case study of sub Saharan Africa. The Electronic Library, 26(4):468-489. http://doi.org/10.1108/02640470810893738

Mutula, S. M. (2013). Ethical Dimensions of the Information Society: implications for Africa. In: Ocholla, D. Britz, J.J., Capurro, R., Bester C. (Eds). Information Ethics in Africa: Cross-cutting Themes. 29-43.

Ocholla, D.N, (2007). Marginalized Knowledge: An Agenda for Indigenous Knowledge Development and Integration with other Forms of Knowledge. International Review on Information Ethics. Vol. 7

Ocholla, D.N. (2009). Information ethics education in Africa. Where do we stand?. The International Information and Library Review, 41:79-88. Elsevier.

Ocholla, D. N. (2013). What is African Information Ethics?. Information ethics in Africa: Cross-cutting themes, 21-28.

Ocholla, D., Britz, J., Capurro, R., Bester, C. (2013). Information ethics in Africa: Cross-cutting themes. Pretoria, South Africa: African Centre of Excellence for Information Ethics (ACEIE).

Olinger, H. N., Britz, J. J. and Olivier, M. S. (2005). Western Privacy and Ubuntu: Influences in the forthcoming data privacy bill. In: Brey, P., Grodzinsky, F. and Introna, L (Eds): Ethics and New Information Technology. CEPE 2005. Emschede. The Netherlands, 291-305.

Ramose. M. B. (2002). Globalization and ubuntu. In: Coetzee, P. and Roux, A. Philosophy from Africa. A text with readings. Oxford University Press $\left(2^{\text {nd }}\right.$ edition).

South African Government, Department of Education (2004). White Paper on eEducation. Transforming Learning and Teaching through Information and 
Communication Technologies. Notice 1922 of 2004. Government Gazette No. 26762. (September 2004)

Taylor, C. (2002). Democracy, inclusive and excusive. In: Madsen, R., Sullivan, W.M., Swiderl, A., Tipton, S.M. (Eds). Meaning and Modernity: Religion, polity and self. Berkeley. University of California Press. pp. 183-194

UNESCO. (2003). Cultural and Linguistic Diversity in the Information Society.

UNESCO (2005). Declaration of Principles, the Tunis Agenda and the WSIS Action Line C10 on Information Ethics. Geneva. Switzerland.

UNESCO. (2008). ACEIE Report. Information ethics and e-governance training workshop. Pretoria

UNESCO. (2006). Ethiopia holds national digital preservation workshop.

http://www.unesco.org/new/en/communication-andinformation/resources/news-and-in-focus-articles/allnews/news/ethiopia_holds_national_digital_preservation_workshop/

UNESCO. (2009). National Information Society Policy: A Template. París. http://www.unesco.org/new/fileadmin/MULTIMEDIA/HQ/CI/CI/pdf/ifap/ ifap template.pdf

UNESCO. (2011). Transforming Education: The Power of ICT Policies. http://www.unesco.org/new/fileadmin/MULTIMEDIA/FIELD/Dakar/pdf/ Transforming $\% 20$ Education $\% 20$ the $\% 20$ Power $\% 20$ of $\% 20 I C T \% 20$ Policies . pdf

UNESCO. (2011a). E-Governance.

UNESCO. (2011b). Logical Framework and Policy Matrix as Planning Tools. from https://www.yumpu.com/en/document/view/35870397/logicalframework-and-policy-matrix-as-unesco-bangkok (Retrieved March 28, 2016)

UNESCO. (2013). Towards Knowledge Societies for Peace and Sustainable Development: Final Statement. (February), 24.

UNESCO. (2015). Keystones to foster inclusive Knowledge Societies. Retrieved from https://unesdoc.unesco.org/ark:/48223/pf0000232563

UNESCO/IFAP and UNU-EGOV. (2016a). Knowledge Societies Policy Community.

UNESCO/IFAP and UNU-EGOV. (2016b). Knowledge Societies Policy Handbook.

UNESCO/IFAP and UNU-EGOV. (2016c). Knowledge Societies Policy Library. 
UNESCO/IFAP and UNU-EGOV. (2016d). Knowledge Societies Policy Platform.

University of Pretoria. Department of Communication (2011). Memorandum of Agreement with the University of Pretoria.

University of Oxford. (2019). Digital Ethics Lab: Intercultural Digital Ethics Symposium. Retrieved from https://digitalethicslab.oii.ox.ac.uk/intercultural-digital-ethics-symposium/ (10th December 2019)

World Summit on the Information Society. (2003). WSIS Vision Statements. Verbalised at the 2003 World Summit on the Information Society. $1-58$.

World Summit On The Information Society. (2005). WSIS Outcome Documents. Available at: https://www.itu.int/net/wsis/index.html

\section{Author contribution}

The authors of this manuscript prepared the entirety of it in equal parts.

\section{Editor's notes}

The editor responsible for the publication of this article was Rafael Capurro.

Style editing and linguistic revision to the wording in this text has been performed by Prof. Adj. Hugo E. Valanzano (State University, Uruguay).

Nilzete Ferreira Gomes (Universidade Federal Rural da Amazõnia (UFRA), Pará, Brazil), was in charge of translating from Portuguese to Spanish. 